\title{
RADIOCARBON DATES AND THE EARLIEST COLONIZATION OF EAST POLYNESIA: MORE THAN A CASE STUDY
}

\author{
Philippe Della Casa \\ Dept. of Pre-/Protohistory, University of Zurich, Karl-Schmid-Str. 4, CH-8006 Zurich. Email: phildc@access.uzh.ch.
}

\begin{abstract}
Over the last $30 \mathrm{yr}$, there has been an ongoing debate on the dates and modes of the earliest colonization of East Polynesia, namely the Cook Islands, the 5 archipelagos of French Polynesia, the Hawai'i Islands, Easter Island, and New Zealand. At least 3 alternative models were proposed by Sinoto, Anderson, Kirch, and Conte, but interestingly all these models basically relied on the same set of roughly 200 radiocarbon dates on various organic materials from archaeological excavations as far back as the 1950s. Some of the models differed by $500-1000 \mathrm{yr}$ - for a proposed initial colonization around the turn of the BC/AD eras, if not considerably later. By comparing the different approaches to this chronological issue, it becomes evident that almost all known problems in dealing with ${ }^{14} \mathrm{C}$ dates from archaeological excavations are involved: stratigraphy and exact location of samples, sample material and quality, inbuilt ages and reservoir effects, lab errors in ancient dates, etc. More recently, research into landscape and vegetation history has produced alternative ${ }^{14} \mathrm{C}$ dating for early human impact, adding to the confusion about the initial stages of island colonization, while archaeological ${ }^{14} \mathrm{C}$ dates, becoming increasingly "young" as compared to former investigations, now advocate a rapid and late (post-AD 900) colonization of the archipelagos. As it appears, the Polynesian case is more than just another case study, it's a lesson on ${ }^{14} \mathrm{C}$-based archaeological chronology. The present paper does not pretend to solve the problems of early Polynesian colonization, but intends to contribute to the debate on how ${ }^{14} \mathrm{C}$ specialists and archaeologists might cooperate in the future.
\end{abstract}

\section{INTRODUCTION}

This paper, despite its title, is not primarily intended as a systematic review of recent (and less recent) research into the absolute chronology of East Polynesia. Originating from the keynote lecture introducing the 5th International "Radiocarbon and Archaeology" Symposium, it must rather be understood as a case study on, and moreover a critical appraisal of, the topic of how ${ }^{14} \mathrm{C}$ dating and archaeology have been, and eventually should become, related.

The archipelagos of the so-called "Polynesian triangle" are among the remotest areas of the world: hundreds of islands spread over thousands of square kilometers of an open, endless ocean (Figure 1). At some time in the 2nd millennium BC, people of Austronesian origin began to expand settlement into these islands-it was the first human adventuring into the Pacific (for a recent perspective on the "Lapita" complex see Galipaud 2006).

At a later date-still to be defined more precisely—descendants of these people colonized the east Polynesian archipelagos (Cook Islands and today's French Polynesia: Society, Marquesas, Austral, Tuamotu, and Gambier islands) and, possibly somewhat later, the so-called "outer archipelagos" of the Hawai'i Islands, Rapanui/Easter Island, and New Zealand. Over the last $30 \mathrm{yr}$, there has been an ongoing debate on the dates and modes of the earliest colonization of this part of the Pacific (Sinoto 1970; Kirch 1986; Garanger 1987; Irwin 1992; Spriggs and Anderson 1993; Rolett 1993; Kirch and Ellison 1994; Conte 2000; Anderson and Sinoto 2002 [with older literature]; Anderson et al. 2003; Kennett and Winterhalder 2008; Thomas 2008; Wilmshurst et al. 2008).

This paper will focus on 3 aspects:

1. The former and current models for the colonization of the Pacific, in particular the archipelagos of East Polynesia;

2. The set of ${ }^{14} \mathrm{C}$ dates that forms the backbone of the archaeo-chronology, in particular the early corpus, and its critical assessment;

3. And finally, a discussion of the key problems and prospects of the research.

C 2009 by the Arizona Board of Regents on behalf of the University of Arizona

Proceedings of the 5th International ${ }^{14} \mathrm{C}$ and Archaeology Symposium, edited by Irka Hajdas et al.

RADIOCARBON, Vol 51, Nr 2, 2009, p 681-693 


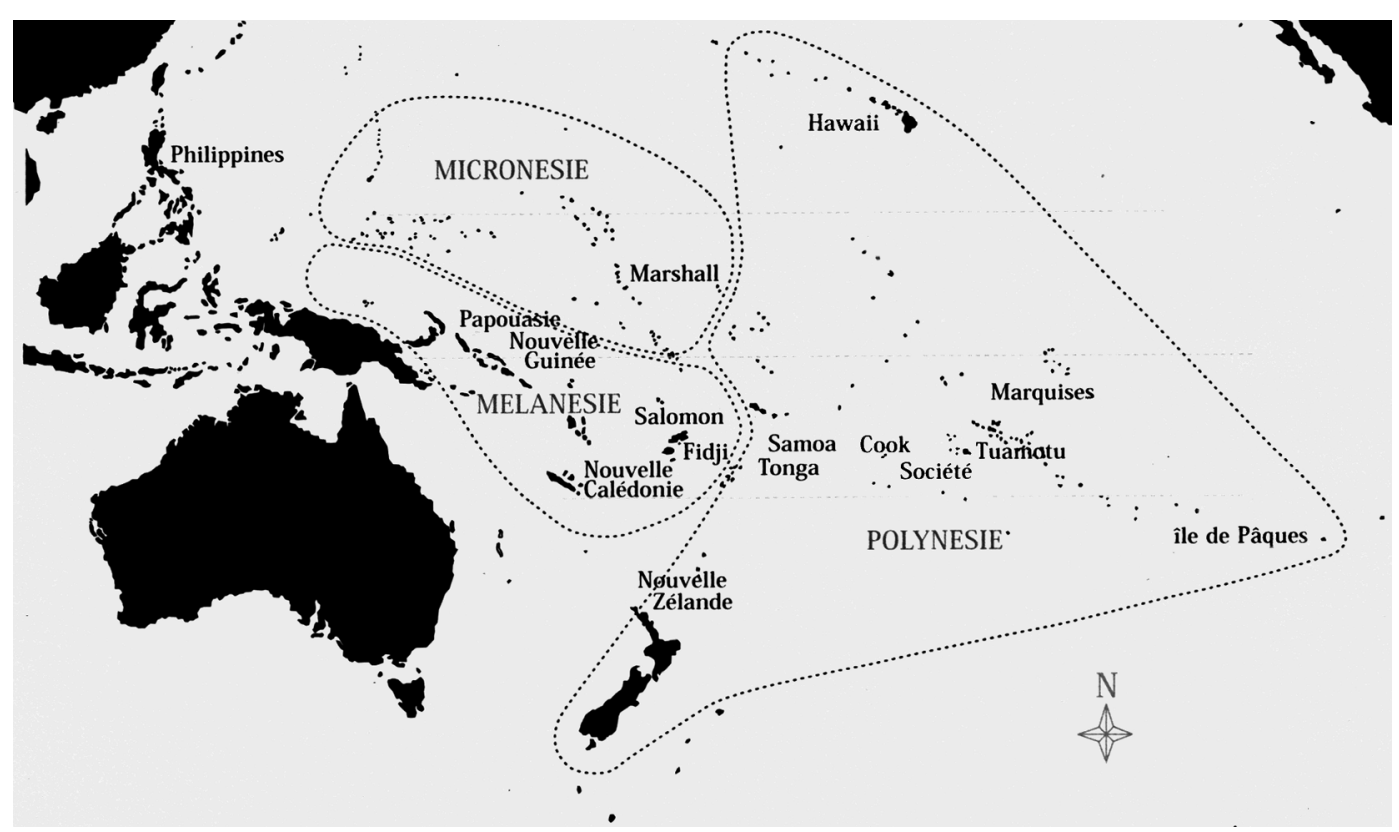

Figure 1 The Polynesian triangle

\section{MODELS FOR COLONIZATION}

In the mid first millennium B.C., the Pacific waters rolling eastward from the ancestral homeland were trackless unknown, as intergalactic space is to twentieth-century man (Kirch 1984:71).

Nowhere on the globe is the relationship between high-skilled seafaring and early human colonization more evident than in the Pacific: many islands have small landmasses, some-as the Tuamotu atolls - none at all, and sight navigation is only possible within the archipelagos. Yet by far the major part of the Pacific islands are inhabited, and have been so for many hundred years.

The processes of exploration and discovery into the Pacific, the modes of the colonization in the different archipelagos and islands, and the initial patterns of settlement with their economic and social backgrounds still remain widely unknown. Along with material culture and stone architecture, which from the beginnings of Polynesian archaeology played an important role in culture history (see e.g. Kirch and Kahn 2007), much of the discussion about the colonization of the Polynesian islands has focused on issues of chronology, on timely sequences, and on dating and localizing the earliest spots of human presence. ${ }^{14} \mathrm{C}$ dates have played, and indeed still play, a central role.

However, discovery and colonization of remote islands is as much a matter of seafaring as of settlement, and the 2 topics are thus closely related. To understand the background of human presence in the Pacific, one needs at least have some notions on navigation and sea voyaging.

The early view, to the 1950s/60s, was one of undirected and fortuitous exploration of the ocean that would eventually lead to the discovery of unknown islands (Sharp 1956; cf. Kirch 1984 supra). However, the navigational skills of the Polynesians were known from a rich mythical background, and from many observations of the European explorers such as Bougainville, Cook, Lapérouse, and Dumont-d'Urville (Conte 1986). 


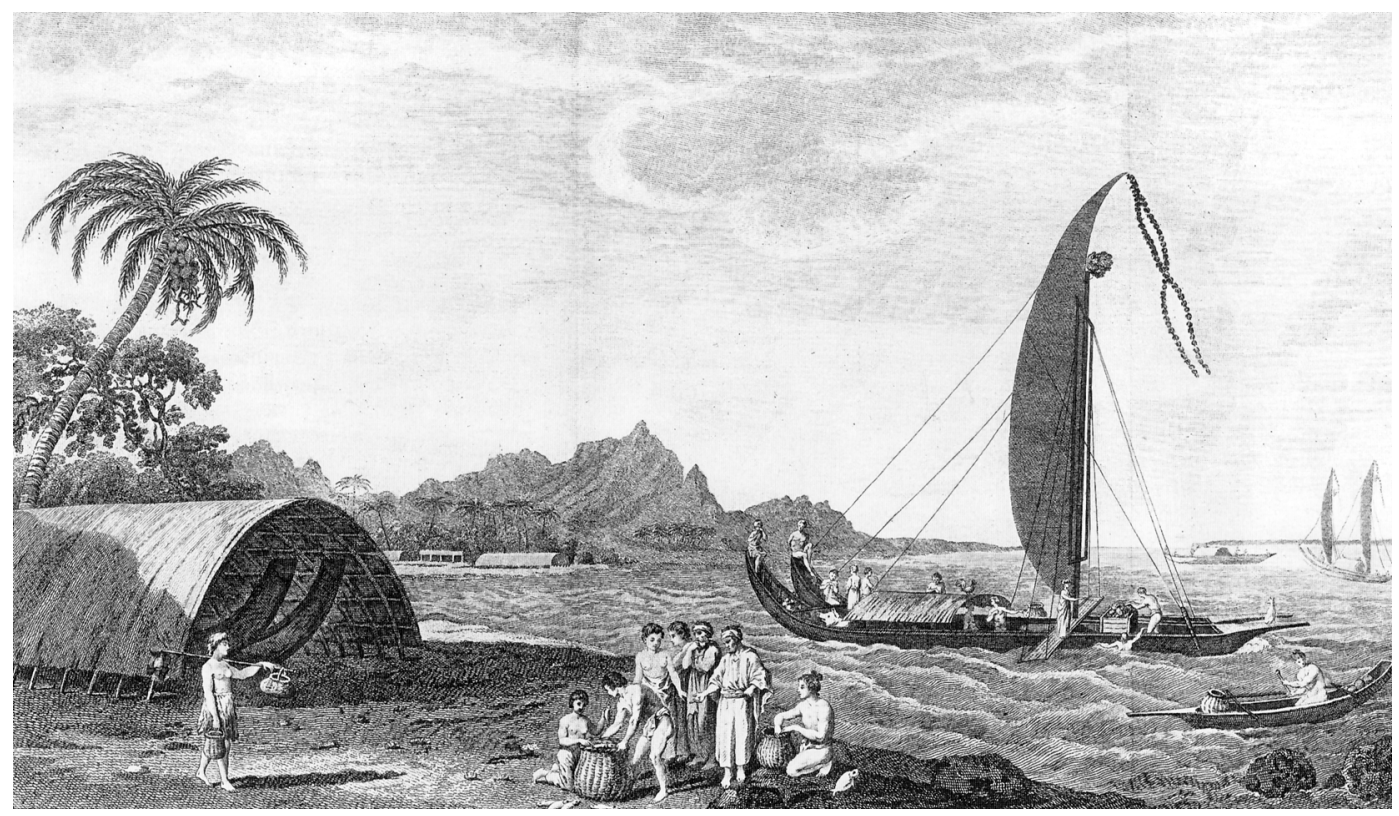

Figure 2 Two-hulled canoes in Raiatea. Engraving by E Rooker from S Parkinson, 1773.

Lewis and Finney, in the late 1960s and early 70s, intensified studies on ancient techniques of navigation and ancient boats, in particular the 2-hulled canoes well known from early ethnographic representations (Lewis 1972; Finney 1979a; see Figure 2). This research finally led to the Hokule'a adventure, a replica of a Wa'a Kaulua sailing canoe, whose first voyage from Maui to Tahiti (2200 nautical miles) between 1 May and 4 June 1976 covered some $5370 \mathrm{~km}$ (Figure 3), using traditional navigation techniques by sun, moon, stars, waves, and bird's flight; traditional food on board such as fish, breadfruit, sweet potato, banana, pandanus flour, and coconut, and including on board the ship 2 fowls, a pig, and a dog (Finney 1979b; Conte 1995). The successful Hokule'a trip left no doubt to the possibility of intentional sea voyages and island colonization. Since then, Hokule'a has completed several other voyages covering more than 24,000 nautical miles, while other canoes have been built and sailed for similar purposes (Finney 2003; critical note by Anderson 2006a; see also Dening 2003).

Along with these empirical approaches to island colonization, the first models on the chronology and directions of human settlement in the Polynesian triangle emerged. Lacking substantial sources of a different kind (such as e.g. relative archaeological typochronologies), these models-from the beginning - essentially relied on ${ }^{14} \mathrm{C}$ dates (Sinoto 1970; Spriggs and Anderson 1993; Conte 2000). It can be reminded here that in the 1950s, Libby provided some of the first archaeological ${ }^{14} \mathrm{C}$ dates to Emory's early research in Polynesia.

For the following discussion (cf. Table 1), we will leave aside colonization models that rely on oral tradition (cf. Buck 1938) because of their apparent incompatibility to models originated from archaeological chronology-building.

Irrespective of the controversies in the detailed chronology, all the models agree that the origin of the colonization movement, and thus the ancestral homeland-the Hawaiki (cf. Kirch and Green 2001) - must be looked for in West Polynesia, in the archipelagos of Samoa and Tonga, and in the context of the so-called "Lapita" cultural complex, at some time late in the 2nd millennium BC. 

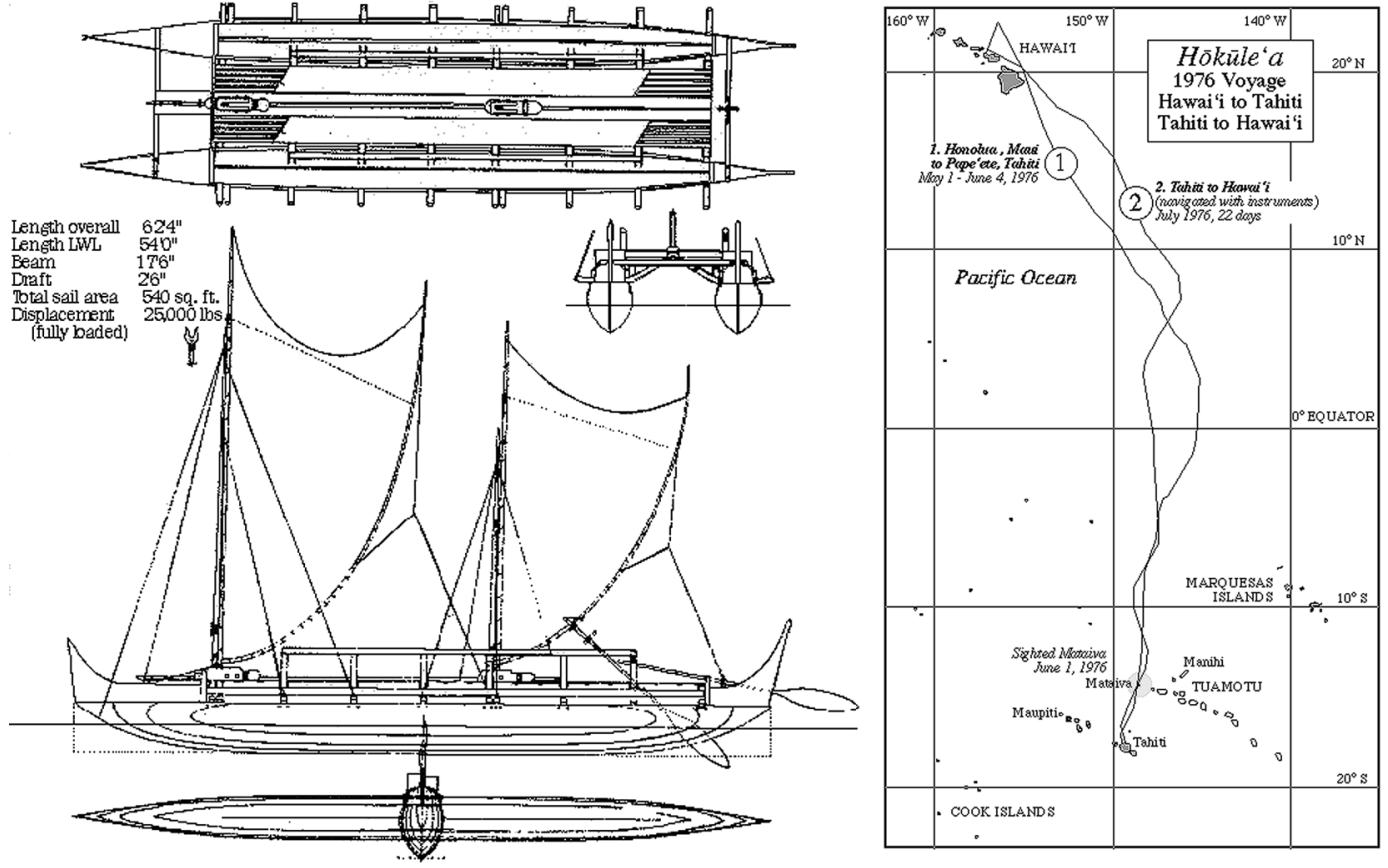

Figure 3 Hokule'a and her trip from Maui to Tahiti 1976 (reprinted with permission of the Polynesian Voyaging Society)

Table 1 Colonization models for East Polynesia.

Oral tradition model

priority: Society Islands: Raiatea

Discontinuous model

priority: Marquesas: from $150 \mathrm{BC}$

(AD 300, 600)

central and outer archipelagos:

AD 400/600-1000/1200

Continuous model

all central archipelagos: from $500 \mathrm{BC}$

(300/200 BC, AD 500)

outer archipelagos: AD 300/500, 700/1000

Stop and pulse model

east Polynesia: from AD 900
Buck 1938

Sinoto 1970; Jennings 1979; Spriggs and Anderson 1993

Kirch 1986; Irwin 1992; Rolett 1993; Conte 1995

Anderson 2001; Kennett and Winterhalder 2008; Thomas 2008

Likewise, the first-generation models concentrated on the Marquesas as the center of East Polynesian colonization-mostly due, as it appears today, to the fact that early ${ }^{14} \mathrm{C}$ dates had been obtained in this island group (Conte 2000:104ff). A gap—or standstill—of more than $1000 \mathrm{yr}$ was envisaged between Lapita and the first trips eastwards. From the Marquesas, subsequent but discontinuous movements would lead to the colonization of Rapanui (Easter Island) and Hawai'i, the remaining archipelagos of French Polynesia (Society Islands, possibly the Tuamotus), and eventually New Zealand, but not before AD 800 (Figure 4, left). 

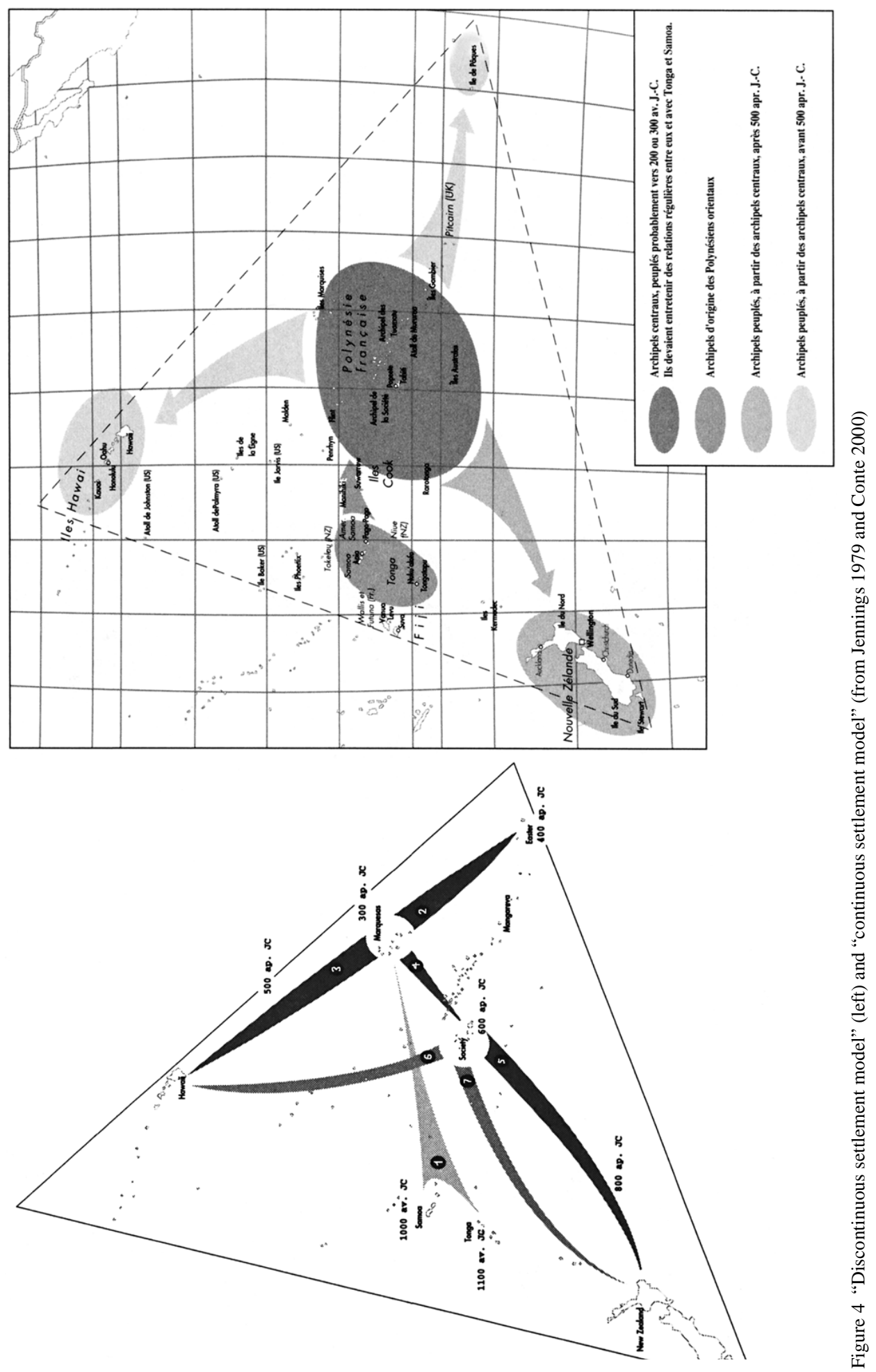
Under the influence of more structured research into the probabilities and possibilities of open-sea navigation and settlement movements (e.g. Irwin 1992; see discussion below), a second generation of colonization models came to challenge traditional views. These models differed insofar as they postulated a continuous and repeated spread of settlement into the central East Polynesian archipelagos from around 500/200 BC instead of highly directional colonization movements, with the exception of the outlying island groups of Rapanui, Hawai' $i$, and New Zealand, for which considerably later dates were maintained (Conte 2000:108ff).

Conte's model, originally subdivided into 6 stages (Conte 1995:36-7), summarizes these trends in chronology building (Figure 4, right). However, when it comes to details, in particular details of chronology, there is no agreement among the researchers. Furthermore, newest trends in modeling chronology now again favor a discontinuous "stop and pulse" scenario (Anderson 2001; Thomas 2008: Figure 4), and a substantially later onset of colonization of the east Polynesian island groups.

\section{RADIOCARBON DATES}

Apart from the fact that the different models advocate different modes of human spread and colonization, they also rely on individual chronologies, both long and short: for central East Polynesia, be it the Marquesas or any other island group, dates for the onset of colonization vary at least between $500 \mathrm{BC}$ and $\mathrm{AD} 500$, now even $\mathrm{AD} 900$. Yet all chronologies, long and short, were-until very recently (Conte 2000; Anderson and Sinoto 2002) — based more or less on the same set of ${ }^{14} \mathrm{C}$ dates. How could this be?

To answer this question, we need first to have a closer look at the ${ }^{14} \mathrm{C}$ data set itself. As for the turn of the century, a set of some 200 pre- $1000 \mathrm{BP}{ }^{14} \mathrm{C}$ dates had accumulated and become available for the discussion of early chronology in East Polynesia (Table 2). Of these, the major part concerned either Hawai'i or New Zealand, whereas only 30 dates related to the-at least in terms of early colonization-crucial central archipelagos of the Cook, Society, and Marquesas islands (no dates were at this time available for the Tuamotus, Australs, and Gambier).

Table 2 Set of pre-1000 BP ${ }^{14} \mathrm{C}$ dates (until about AD 2000).

\begin{tabular}{ll}
\hline & Cook islands 5 \\
East Polynesian central & Society islands 8 \\
archipelagos: 29 dates & Marquesas 16 \\
\hline Easter island: 8 dates & \\
Hawai'i islands: 109 dates & \\
New Zealand: 38 dates & \\
\hline
\end{tabular}

It must be noted here that since the year 2000, there has been a considerable increase of available ${ }^{14} \mathrm{C}$ dates for various archipelagos of East Polynesia, in particular the Society Islands and Marquesas, the Gambier Islands, Hawai'i, New Zealand, and Rapanui (see Kennett and Winterhalder 2008:89ff with bibliography). However, very few, if at all, touch the period before $1000 \mathrm{BP}$, of specific interest in the discussion of the initial stages of colonization. This trend towards younger ${ }^{14} \mathrm{C}$ dates is a conspicuous feature of the most recent chronology discussion (see below).

For a long time, archaeologists made rather free use of the ${ }^{14} \mathrm{C}$ dates, irrespective of the many problems inherent, such as early excavations and lacking or insecure archaeological contexts, questions of taphonomy and conditions of preservation, inbuilt ages (e.g. driftwood), and reservoir effectsthe latter being of particular importance since the data come from a great variety of materials such as charcoal and wood, marine shell, land snails, bird bone, fish bone, or human bone (cf. Anderson 
and Sinoto 2002). Again, systematic approaches to these problems only emerged in the last few years (cf. Anderson et al. 2003).

\section{CRITICAL ASSESSMENT OF THE DATA SET}

Since ${ }^{14} \mathrm{C}$ dates were often accepted or rejected on a rather arbitrary basis, Spriggs and Anderson (1993) proposed a rigorous critical approach to establish ${ }^{14} \mathrm{C}$ dates as either acceptable, questionable, or unacceptable. This approach - which led to the exclusion of $80 \%$ of the then-available ${ }^{14} \mathrm{C}$ dates-was based on a set of 17 protocols ("criteria," see Table 3 ) of which the negative ones can be grouped into 3 categories:

- unreliable laboratories or laboratory procedures,

- unreliable materials dated,

- problematic archaeological contexts.

Results were accepted where:

- dates and archaeological contexts match,

- several samples gave comparable results,

- dates are in stratigraphic order, or are on identified short-lived material.

Table 3 Selection of criteria used by Spriggs and Anderson (1993) for "chronometric hygiene."

\begin{tabular}{ll}
\hline Negative criteria & A: early Gakushuin lab dates \\
& B: unsuitable material (fish, human, or animal bone) \\
C: stratigraphic inversion \\
E: charcoal from basal agricultural contexts \\
F: no clear cultural context \\
G: anomalous compared to same cultural context elsewhere \\
H: high inbuilt age suspected (“old wood”) \\
J: inadequately pretreated \\
L: single unidentified dates \\
M: mixed samples \\
N: single date with associated material \\
O: comparable results from different features or single stratum \\
P: tight series in stratigraphic order \\
Q: short lifespan material and adjusted for $\delta^{13} \mathrm{C}$ \\
\hline
\end{tabular}

To fully understand the problem, a more detailed look into some paradigmatical situations is needed. With exception of the-according to Spriggs and Anderson questionable-dates from Pukapuka in the Northern Cooks, no dates earlier than AD 800 seem acceptable for the Southern Cook Islands (cf. Rakahanga, and Ureia on Aitutaki). In the Marquesas, few sites had so far produced early - that is pre-BC/AD transition-dates, the most important being the dune sites of $\mathrm{Ha}$ 'atuatua on Nuku Hiva, and Hane on Ua Huka.

One more site, the rockshelter Anapua on Ua Pou dug by Ottino in 1982, gave a charcoal date calibrated to 390 BC-AD 280. Spriggs and Anderson declined this early sample because a date some 1300 yr younger was obtained on marine shell from the same context (Conte 2000:115).

The Ha'atuatua dune was excavated by Suggs in 1956-57 in 2 areas (A, B), which both gave early ${ }^{14} \mathrm{C}$ dates calibrating to $410 \mathrm{BC}-\mathrm{AD} 240$ and $380 \mathrm{BC}-\mathrm{AD}$ 530, respectively. These dates were among the key arguments for an early settlement of central East Polynesia and the Marquesas in particular (Kirch 1986; Rolett 1993). Spriggs and Anderson rejected with their critical arguments the 
date for location $\mathrm{B}$, and held the one for A as questionable. The only secure date according to these authors was one of a AD 610-1270 calibration span. Recent re-examination of the site by Conte and Rolett has produced dates around AD 1500 for location B. In location A, the old trench dug by Suggs was re-opened in order to be sure to get samples from the same stratigraphic contexts: these calibrate around AD 1300 — much younger than the dates originally presented (Conte 2000:113).

Hane on Ua Huka was excavated by Sinoto in 1964/65 in 2 areas (A, B), with the earliest ${ }^{14} \mathrm{C}$ dates of the lower levels calibrated to the timespan 100 BC-AD 270. Again, Spriggs and Anderson's critical revision of the Hane site led to a rather confusing situation, in which e.g. for level VIa/area B dates as different as 100 BC-AD 690 and AD 510-1290 were considered acceptable. In their statistic protocol, this might be correct, but one rightly raises the question what kind of archaeological reality could produce such an assemblage (Conte 2000:114).

Aware of the many problems pertaining to the Hane site, Anderson and Sinoto published a second set of ${ }^{14} \mathrm{C}$ dates from new excavations in both originally investigated areas of the site (Anderson and Sinoto 2002). All of the new dates, predominantly upon samples from the lowest levels of areas A and $\mathrm{B}$, are late - corresponding to the later dates of the first series-with calibration spans around AD 1000-1200. Anderson and Sinoto accord this substantial "younging" of dates to problems of inbuilt ages in charcoal samples and geological effects in shell samples, and to a (systematic) bias in earlier Washington State University lab dates (Anderson and Sinoto 2002: Table 2, Figure 2). They pinpoint in particular unresolved problems with calibration of the marine reservoir. A provocative chronological statement concludes their paper:

....and we will hazard a guess that habitation of any kind may not have begun anywhere in the region before AD 900. In principle, if not in practice, that ought to be an easy proposition to overturn (Anderson and Sinoto 2002:253).

\section{DISCUSSION: ARCHAEOLOGY, COLONIZATION, AND ENVIRONMENT}

Beyond questions of detailed chronology, and seen from a methodological point of view, these examples prove the rather paradoxical situation of a chronology discussion relying almost entirely on ${ }^{14} \mathrm{C}$, the archaeological contexts and associated finds being used to illustrate rather than to build timely sequences, and revealing above all a severe lack of ascertained dates-not only ${ }^{14} \mathrm{C}$ datesfrom pluri-stratified sites.

From an archaeological point of view, questions arise such as: What is the exact nature of the sites under examination, variably used for high or low chronologies? Do they reflect continuous or intermittent occupations? What is their setting in terms of human ecology? Do any of these sites really pertain to the first phase of human occupation, to the "colonization" sensu stricto? What is the significance, in terms of cultural history, of the archaeological material associated with these sites?

The situation encountered in the Marquesas is just one of several similar cases across the Polynesian triangle. Considering the situation in Hawai' $i$, Graves and Addison noted that:

Ironically, the same data—early prehistoric radiocarbon dates from archaeological sites in Hawai'i-are the basis for these ... differing claims regarding the timing of the Polynesian settlement of the archipelago. However, ... we believe that these models diverge in their conclusions because archaeologists have not developed an explicit framework in which to investigate prehistoric settlement processes (Graves and Addison 1995:381).

We should remember here that all colonization models proposed were originally intended as "theoretical models," as a basis for further discussion and investigation (Conte 2000). However, as it hap- 
pens, models tend to be interpreted as a "reality approach," rather than as "simulations of the past" - and developments and discussions in the chronology issue thus became rather controversial arguments, opposing in particular Kirch (long chronology: 1986, 2000) and Anderson (short chronology: 1994, 2002). But then:

If the former remains difficult to prove, then the second is difficult to explain (Irwin 1998:136).

As Graves and Addison (1995) stated for the Hawaiian case, this is not only due to alternative and controversial interpretations of ${ }^{14} \mathrm{C}$ dates, but just as much to a lack of archaeological approaches to the process of colonization itself. They proposed an analytical strategy taking into account 3 steps of an island settlement process (Graves and Addison 1995: Table 1), and a careful and critical discussion of archaeological situations presumably relating to the early stages of island colonization:

Although it is possible that discovery, colonization and establishment may have been relatively simultaneous in archaeological time, they represent distinct components of a settlement process, potentially separated by significant increments of time (Graves and Addison 1995:387).

In their view, a recurring pattern in ${ }^{14} \mathrm{C}$ dates from Hawai'i Island and $\mathrm{O}$ ' ahu-a few samples clearly predating the period of $\mathrm{AD} 600$ usually understood as the onset of colonization-could be attributed to an early discovery or colonization phase, whereas the later dates would pertain to the actual establishment of human populations on the archipelago.

Graves and Addison's proposals relied on new insights into the background and modes of early navigation by Irwin (1992), using — among other tools — charts of winds and currents, target angles of presumed systematic navigation, as well as computer simulations of inter-island voyages, and of which major issues concerning colonization stipulated that it must be seen as a highly intentional process using systematic upwind navigation and return voyages, and that it must be understood as a continuous process of learning and expanding, of failure and success.

Using a logarithmic transformation of a Mercator projection, Irwin suggested a continuous, radial model of the spread of human settlement into the Polynesian archipelagos, based on distances and again the available ${ }^{14} \mathrm{C}$ dates (Irwin 1992: Figure 24). Using Lapita dates as a starting point for his radial model, Irwin's chronology was inevitably a long one (cf. below and Figure 5).

In the controversial issue of opposing models of late and early colonization (and thus short and long chronologies), new arguments were introduced in the 1990s by paleoenvironmental research, in particular on Mangaia island in the Southern Cooks. Based on a substantial series of sedimentological and palynological cores taken in swampy catchment areas of the island, Kirch and colleagues claimed evidence of human impact due to forest clearance aided by fire as far back as $2500 \mathrm{BP}$ or the mid-1st millennium BC in calibrated age, and thus at least $1000 \mathrm{yr}$ earlier than any known archaeological site on the island (Kirch and Ellison 1994). This is evidenced by rapid replacement of peats by alluvial clays, sustained geochemical changes, sudden and massive appearance of charcoal, and dramatic reductions of forest taxa along with increases of ferns as well as of Pandanus tectorius, today a dominant plant of the interior ridges (Kirch and Ellison 1994: Figure 3). Their conclusions are far-reaching:

We suggest that the important issue of establishing the chronology of human colonization and occupation of Remote Oceania will not be resolved solely by applying "chronometric hygiene" to the available suite of radiocarbon dates from known habitation sites. Indeed, there are good reasons to believe that for many East Polynesian islands and archipelagos no sites dating to the initial colonization phases have yet been discovered (Kirch and Ellison 1994:319). 


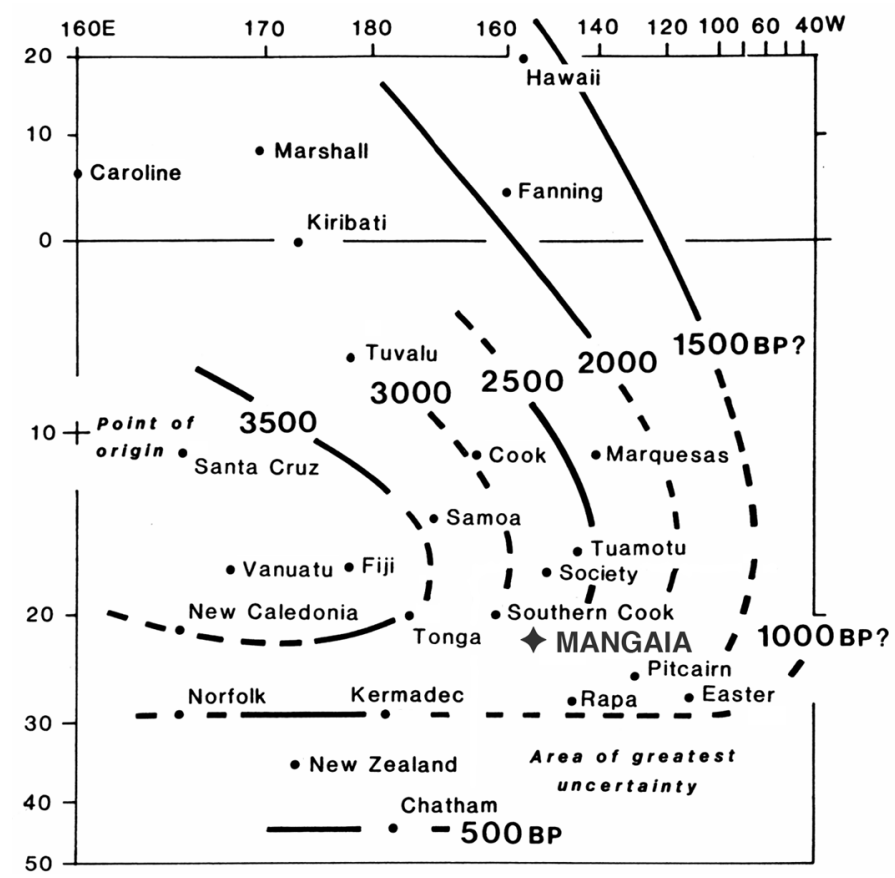

Figure 5 Mangaia Island early human impact date (Kirch and Ellison 1994), fitted into Irwin's (1992) logarithmic transformation.

These results were again contested by Anderson (1994), partly because of possible contamination of the deposits by old carbon from the carbonate makatea ridge of the island, and partly because of the absence of cultigens in the pollen record and the possibility that the post-2500 BP event actually dates natural processes due to changing climate. However, the proposed Mangaia date would well fit into Irwin's model (Figure 5) - if a continuous mode of colonization and spread of settlement had become acceptable for the whole of East Polynesia, which is currently, as seen in Table 1, not the case, in particular as the dates for the onset of this process are insecure, and possibly much later than originally held.

Concerning the role of targeted navigation in the colonization process, research has recently focused on simulations of drift voyaging, and the possibilities of accommodating concepts of both intentional and sequential movements of migration (Avis et al. 2007; Callaghan and Fitzpatrick 2008; Irwin 1998, 2008). These new models can be accorded with the relatively late ${ }^{14} \mathrm{C}$ dates now available for East Polynesia and used for the "stop and pulse" model.

However, to choose among long and short scenarios is not a mere question of chronology, of time and scale - it has far-reaching implications in the scientific discourse, as we should remember that as archaeologists it is not so much time we are interested in, but history:

A shortened prehistory allows less time for socio-cultural developments which are evolutionary in character, and therefore it is more likely that the widespread phenomenon of chiefdoms reflects an ancestral form, rather than any significant convergent development. Proposed scenarios of demographic growth and cultural change, including rates of linguistic divergence between island groups, will also need to be reconsidered (Spriggs and Anderson 1993:214). 
Thus, it appears, in a lack of valuable alternatives, "absolute chronology controls history" (cf. Anderson and Sinoto 2002:253). There is certainly still a great need to strengthen traditional archaeological evidence in a discourse of culture history, not just cultural chronology (Kennett and Winterhalder 2008).

\section{CONCLUSIONS, TAKING A LOOK AT SITUATIONS IN EUROPE}

This brief discussion of selected items in the problems of dating the initial stages of colonization in East Polynesia by ${ }^{14} \mathrm{C}$ dates serves the purpose of illustrating a complex situation that cannot be fully discussed here. As already mentioned, substantial amounts of new dates from recent excavations have been published since Spriggs and Anderson's 1993 paper; they all follow a general trend: they tend to be considerably younger (no older than $1000 \mathrm{BP}$ ) and much more consistent than the older available dates.

As examples, we may cite the thus-far earliest dates for Mangareva (Rikitea, Louis' Place) at AD 1160-1220 (but possibly not of the initial colonization), following careful and controlled sampling and sample treatment, and taking particular care of the "in-built age potential" (Anderson et al. 2003); new young dates for the Marquesan and Hawaiian archipelagos for a foundation period between AD 800-1200 (Allen 2004; Kirch and McCoy 2007); or a series of young dates indicating late colonization of Rapanui (Hunt and Lipo 2006). Additional arguments follow different lines of evidence, for example, the ${ }^{14} \mathrm{C}$ chronology of the dispersal of the commensal rat (Wilmshurst et al. 2008) along with human colonization (see Kennett and Winterhalder 2008 for a complete survey of recent issues).

The balance is now clearly in favor of a short chronology and a discontinuous model of colonization. The "older" dates, even those that had passed the tests of "chronometric hygiene" (see above), seem to have disappeared from the discussion, which, at least from a methodological point of view, is not unproblematic. Furthermore, it remains to be proven whether new chronological challenges such as the contact scenario between the Hawaiians or Marquesans and the North American mainland recently advocated by Jones and Klar (2005) for the period AD 400-800 can be as easily dismissed with chronological arguments (see Anderson 2006b and reply by Jones and Klar 2006).

This paper was not meant to solve the problems of early East Polynesian colonization. However, the situation encountered in Polynesia is in many aspects typical of archaeological chronology discussions, and allows us to point to more general methodological issues and also to draw a couple of parallels with the European continent, the core area of the 5th "Radiocarbon \& Archaeology" symposium.

Random sampling, unresolved stratigraphies, inadequate dating procedures, ${ }^{14} \mathrm{C}$ dates without proper contexts, unrecognized lab errors, reservoir effects, etc.: eventually, these will always cause problems. And likewise, post factum re-evaluation of unobserved archaeological situations will always remain problematic, regardless of the amount of available chronometric dates. Beyond sophisticated methods of sample handling and data modeling, intensive dialogue between archaeologists, environmentalists, and ${ }^{14} \mathrm{C}$ specialists remains a great challenge (cf. Denaire; Stöckli; Müller, this volume) - hence the importance of encounters such as the "Radiocarbon \& Archaeology" symposia (Evin et al. 1999; Higham et al. 2004).

Similar to the situation in Polynesia, the spread of the Neolithic across Europe has been largely debated in terms of absolute chronology, and "chronometric hygiene"-e.g. on early dates in Greece, the Balkans, or southern Italy_-is being discussed and appears necessary to reach a coherent scenario (cf. Reingruber and Thissen, this volume). However, research into the nature of 
Neolithic island sites in the Mediterranean have shown how discrete early human presence could be, and how frail current concepts of "Neolithic colonization" appear in the light of new data (cf. shortlived EN sites on the Croatian island of Susac: Bass 1998, 2008). We would also be mistaken to claim that the revised chronology has freed us from problems of interpretation: recently, palynological evidence of early cultigens in 8th/7th millennium BC Europe-way ahead of the Neolithic colonization-has come to challenge traditional views of the spread of crop production (Behre 2007; Tinner et al. 2007). Likewise, the first reports of early human impact and markers in 4th millennium BC Alpine sediment cores (Burga 1976) were met with doubt and disapproval, until the iceman from the Similaun (Höpfel et al. 1992) triggered a new area of environmental and archaeological research into the early human colonization of the Alps. If an early phase of sedentary human presence in the Alps is now widely accepted, environmental phenomena such as the rise of Alnus viridis are still a matter of the debate climatic versus human impact (Della Casa 2000:172ff). More recently, extensive surveys in high-altitude regions of the Silvretta (CH/A) have led to the discovery of still earlier, very discrete sites of human presence with ${ }^{14} \mathrm{C}$ dates calibrating to the 5 th millennium $\mathrm{BC}$ (Reitmaier and Walser 2008). As with recent approaches to Polynesian prehistory (Anderson 2002), these researches are embedded in a wider archaeological and environmental context, in which material culture and chronometric dating are just 2 of many aspects. Let us thus remember that:

There is no simplified version of social reality for archaeologists to use (Coudart and Lemonnier 1984:

167-cited, though in a different context, in Conte 2006).

\section{REFERENCES}

Allen M. 2004. Revisiting and revising Marquesan culture history: new archaeological investigations at Anaho Bay, Nuku Hiva Island. Journal of the Polynesian Society 113(2):143-96.

Anderson A. 1994. Palaeoenvironmental evidence of island colonization: a response. Antiquity 68:845-7.

Anderson A. 2001. Mobility models of Lapita migration. In: Clark G, Anderson A, Vunidilo T, editors. The Archaeology of Lapita Dispersal in Oceania. Terra Australis 17. Canberra: ANU. p 15-23.

Anderson A. 2002. Faunal collapse, landscape change and settlement history in Remote Oceania. World Archaeology 33(3):375-90.

Anderson A. 2006a. Review of B. Finney 2003, Sailing in the Wake of the Ancestors. Asian Perspectives 45(1):126-7.

Anderson A. 2006b. Polynesian seafaring and American horizons: a response to Jones and Klar. American Antiquity 71(4):759-63.

Anderson A, Sinoto Y. 2002. New radiocarbon ages of colonization sites in East Polynesia. Asian Perspectives 41(2):242-57.

Anderson A, Conte E, Kirch PV, Weisler MI. 2003. Cultural chronology in Mangareva (Gambier islands), French Polynesia: evidence from recent radiocarbon dating. Journal of the Polynesian Society 112(2):119 40.

Avis C, Montenegro A, Weaver A. 2007. The discovery of western Oceania: a new perspective. Journal of Island and Coastal Archaeology 2(2):197-209.

Bass B. 1998. Early Neolithic offshore accounts: remote islands, maritime exploitations, and the trans-Adriatic cultural network. Journal of Mediterranean Archaeology 11(2):165-90.

Bass B. 2008. Early Neolithic communities in southern Dalmatia: farming seafarers or seafaring farmers? $E u$ ropean Journal of Archaeology 11(2-3):245-65.

Behre KE. 2007. Evidence for Mesolithic agriculture in and around central Europe? Vegetation History and Archaeobotany 16(2-3):203-19.

Buck PH. 1938. Vikings of the Sunrise. New York: F.A. Stockes Co.

Burga C. 1976. Frühe menschliche Spuren in der subalpinen Stufe des Hinterrheins. Geographica Helvetica 2:93-6.

Callaghan R, Fitzpatrick SM. 2008. Examining prehistoric migration patterns in the Palauan archipelago: a computer simulated analysis of drift voyaging. Asian Perspectives 47(1):28-44.

Conte E. 1986. La navigation hauturière: un art disparu. In: La vie quotidienne dans la Polynésie d'autrefois. Encyclopédie de la Polynésie, volume 5. Papeete: Gleizal-multipress.

Conte E. 1995. Tereraa. Voyage et peuplement des îles du Pacifique. Tahiti: Polymages-Scoop.

Conte E. 2000. L'archéologie en Polynésie française. Esquisse d'un bilan critique. Tahiti: Aux vent des îles.

Conte E. 2006. Ethnoarchaeology in Polynesia. In: Lilley I, editor. Archaeology of Oceania: Australia and the Pacific Islands. Malden: Blackwell. p 240-58.

Coudart A, Lemonnier P. 1984. Ethnoarchéologie et ethnologie des techniques. Techniques et Cultures 3:15769.

Della Casa P. 2000. Mesolcina praehistorica. Mensch und 
Naturraum in einem Bündner Südalpental vom Mesolithikum bis in römische Zeit. Universitätsforschungen zur Prähistorischen Archäologie 67. Bonn: Habelt.

Dening G. 2003. Voyaging the past, present, and future. Historical reenactments on HM Bark Endeavour and the voyaging canoe Hokule' $a$ in the Sea of Islands. In: Nussbaum FA, editor. The Global Eighteenth Century. Baltimore: John Hopkins University Press. p 309-24.

Evin J, Oberlin C, Daugas J-P, Salles J-F, editors. 1999. ${ }^{14} \mathrm{C}$ et Archéologie. Actes du $3{ }^{\text {ème }}$ Congrès International, Lyon 1998. Mémoires de la Société Préhistorique Française 26. Rennes: Université.

Finney B. 1979a. Voyaging. In: Jennings JD, editor. The Prehistory of Polynesia. Cambridge: Harvard University Press.

Finney B. 1979b. Hokule'a: The Way to Tahiti. New York: Dodd Mead

Finney B. 2003. Sailing in the Wake of the Ancestors: Reviving Polynesian Voyaging. Honolulu: BP Bishop Museum Press.

Galipaud J-C. 2006. The first millennium B.C. in remote Oceania: an alternative perspective on Lapita. In: Lilley I, editor. Archaeology of Oceania: Australia and the Pacific Islands. Malden: Blackwell. p 228-39.

Garanger J. 1987. Le peuplement de l'Océanie insulaire. L'Anthropologie 91:803-16.

Graves MW, Addison DJ. 1995. The Polynesian settlement of the Hawaiian Archipelago: integrating models and methods in archaeological interpretation. World Archaeology 26(3):380-99.

Higham T, Bronk Ramsey C, Owen C, editors. 2004. Radiocarbon and Archaeology. 4th International Symposium, Oxford 2002. Oxford: University School of Archaeology, Monograph 62.

Höpfel F, Platzer W, Spidler K. 1992. Der Mann im Eis 1. Innsbruck: Veröffentlichungen der Universität Innsbruck 187.

Hunt TL, Lipo CP. 2006. Evidence for a shorter chronology on Rapa Nui (Easter Island). Journal of Island and Coastal Archaeology 3(1):140-8.

Irwin G. 1992. The Prehistoric Exploration and Colonisation of the Pacific. Cambridge: Cambridge University Press.

Irwin G. 1998. The colonization of the Pacific: chronological, navigational and social issues. Journal of the Polynesian Society 107:111-44.

Irwin G. 2008. Pacific seascapes, canoe performance, and a review of Lapita voyaging with regard to theories of migration. Asian Perspectives 47(1):12-27.

Jennings JD, editor. 1979. The Prehistory of Polynesia. Cambridge: Harvard University Press.

Jones TL, Klar KA. 2005. Diffusionism reconsidered: linguistic and archaeological evidence for prehistoric Polynesian contact with southern California. American Antiquity 70(3):457-84.

Jones TL, Klar KA. 2006. On open minds and missed marks: a response to Atholl Anderson. American Antiquity 71(4):765-70.

Kennett DJ, Winterhalder B. 2008. Demographic expan- sion, despotism and the colonisation of East and South Polynesia. In: Clark G, Foss Leach B, O'Connor S, editors. Islands of Inquiry. Colonisation, Seafaring and the Archaeology of Maritime Landscapes. Terra Australis 29. Canberra: ANU. p 87-96.

Kirch PV. 1984. The Evolution of the Polynesian Chiefdoms. Cambridge: Cambridge University Press.

Kirch PV. 1986. Rethinking East Polynesian prehistory. Journal of the Polynesian Society 95:9-40.

Kirch PV. 2000. On the Road of the Winds. An Archaeological History of the Pacific Islands before European Contact. Berkeley: University of California Press.

Kirch PV, Ellison J. 1994. Palaeoenvironmental evidence for human colonization of remote Oceanic islands. Antiquity 68(259):310-21.

Kirch PV, Green RC. 2001. Hawaiki, Ancestral Polynesia. An Essay in Historical Anthropology. Cambridge: Cambridge University Press.

Kirch PV, Kahn JG. 2007. Advances in Polynesian prehistory: a review and assessment of the past decade (1993-2004). Journal of Archaeological Research 15(3):191-238.

Kirch PV, McCoy MD. 2007. Reconfiguring the Hawaiian cultural sequence: results of re-dating the Halawa dune site (MO-A1-3), Moloka'i island. Journal of the Polynesian Society 116(4):385-406.

Lewis D. 1972. We, the Navigators. Honolulu: University of Hawai' $i$ Press.

Reitmaier T, Walser C. 2008. Archäologie an der Grenze-Zum neuen Forschungsprojekt "Rückwege" in der Silvretta. Montfort, Vierteljahresschrift für die Geschichte und Gegenwart Vorarlbergs 60:7-15.

Rolett BV. 1993. Marquesan prehistory and the origins of East Polynesian culture. Journal de la Société des Océanistes 96:29-47.

Sharp A. 1956. Ancient Voyagers in the Pacific. Polynesian Society Memoir 32. Wellington.

Sinoto YH. 1970. An archaeologically based assessment of the Marquesas Islands as a dispersal center in East Polynesia. Pacific Anthropological Records 11:10532.

Spriggs M, Anderson A. 1993. Late colonization of East Polynesia. Antiquity 67(255):200-17.

Thomas T. 2008. The long pause and the last pulse: mapping East Polynesian colonisation. In: Clark G, Foss Leach B, O'Connor S, editors. Islands of Inquiry. Colonisation, Seafaring and the Archaeology of Maritime Landscapes. Terra Australis 29. Canberra: ANU. p 97-112

Tinner W, Nielsen E, Lotter AF. 2007. Mesolithic agriculture in Switzerland? A critical review of the evidence. Quaternary Science Review 26(9-10):141631.

Wilmshurst JM, Anderson AJ, Higham T, Worthy T. 2008. Dating the late prehistoric dispersal of Polynesians to New Zealand using the commensal Pacific rat. Proceedings of the National Academy of Sciences (USA) 105(22):7676-80. 